\title{
Penggunaan probiotik Lactobacillus paracasei ssp paracasei M13 terenkapsulasi karagenan-skim pada pembuatan Yoghurt Jambu Biji (Yojabi)
}

\author{
Mutia Elida*, Gusmalini, \& Iza Ayu Saufani \\ Politeknik Pertanian Negeri Payakumbuh \\ * elida_mutia@yahoo.com
}

\begin{abstract}
Abstrak. Probiotik Lactobacilllus paracasei ssp paracasei ml3 terenkapsulasi karagenan-skim diaplikasikan dalam pembuatan yoghurt jambu biji sebagai pengganti starter alami dadih untuk menghasilkan yoghurt yang bermutu dan bermanfaat untuk kesehatan. Yoghurt "yojabi" merupakan salah satu produk unggulan PPUPIK probiotik Politani Payakumbuh. Metoda kegiatan yang dilakukan adalah demonstrasi langsung, pelatihan dan pendampingan proses produksi pada kelompok produksi PPUPIK. Starter terenkapsulasi karagenan-skim 3:1 dalam bentuk kapsul basah diinokulasikan sebanyak 3\% ke dalam susu pasteurisasi dan kemudian difermentasi selama 12 jam. Proses selanjutnya adalah homogenizer dengan menambahkan sari buah jambu biji pasteurisasi kemudian dilakukan pengemasan. Hasil yang diperoleh adalah bahwa penggunaan starter terenkapsulasi dalam bentuk kapsul basah memudahkan dalam tahapan produksi, dimana tidak diperlukan pembuatan kultur kerja dan hanya denga $\mathrm{n}$ menambahkan kapsul basah sebagai starter ke dalam wadah fermentasi. Total asam laktat yogurt adalah 1.09\%, pH yoghurt 4.6, dan total bakteri asam laktat 9,2 log cfu/ml, memiliki kadar air 75.84\%, kadar abu 0.69\%, kadar protein 4\%, kadar lemak 3.08\%, karbohidrat total 16.39\%. Analisa finansial diperoleh R/C ratio 1.48 dan BEP harga 3382,30.
\end{abstract}

Kata kunci: enkapsulasi; karagenan; probiotik; yoghurt

\begin{abstract}
Probiotic Lactobacilllus paracasei ssp paracasei Ml3 encapsulated carrageenan-skim was applied in the making of guava yogurt as a substitute for natural starter curd to produce yogurt quality and beneficial for health. Yogurt "yojabi" is one of the flagship products PPUPIK probiotics Politani Payakumbuh. The method of activity is direct demonstrating, training and mentoring production process in the production group PPUPIK. The starter encapsulated carrageenan-skim 2:1 in the form of a wet capsule was inoculated by $3 \%$ into pasteurized milk and then fermented for 12 hours. The next process is a homogenizer by added guava pasteurized fruit juices and then packing. The results are that use encapsulated starter in the form of wet capsules let capsules as a starter into the fermentation container. Total lactic acid yogurt is $1.09 \%, \mathrm{pH} 4.6$, and total lactic acid bacteria $9,2 \log \mathrm{CFU} / \mathrm{ml}$, water content of $75.84 \%$, ash content of $0.69 \%$, protein levels of $4 \%$, fat content $3.08 \%$, and total carbohydrate $16.39 \%$. Financial analysis obtained $\mathrm{R} / \mathrm{C}$ ratio 1.48 , and price BEP 3.382,30.
\end{abstract}

Keywords: carageenan; encapsulated; probiotic; yoghurt

To cite this article: Elida, M., Gusmalini, \& I. A. Saufani. 2019. Penggunaan probiotik Lactobacillus paracasei ssp paracasei M13 terenkapsulasi karagenan-skim pada pembuatan Yoghurt Jambu Biji (Yojabi). Unri Conference Series: Community Engagement 1: 584-589 https://doi.org/10.31258/unricsce.1.584-589

(C) 2019 Authors

Peer-review under responsibility of the organizing committee of Seminar Nasional Pemberdayaan Masyarakat 2019 


\section{PENDAHULUAN}

Kegiatan Program Pengembangan Produk Intelektual Kampus (PPUPIK) berbasis pangan probiotik pada tahun I dikembangkan produk kering berupa aneka cookies probiotik, sedangkan pada tahun ke II difokuskan kepada minuman probiotik aneka rasa, ice krim yoghurt. dan aneka cookies probiotik. Pada tahun ke III dilakukan penambahan produk probiotik yaitu yoghurt aneka rasa seperti jambu biji, sirsak, dan buah naga. Produk probiotik yang dibuat pada tahun I dan ke II menggunakan dadih sebagai starter, karena dadih mengandung berbagai jenis asam laktat yang dapat menfermentasi susu.

Penyediakan kultur starter pada Mitra PPUPIK ini membutuhkan 3 tahapan mulai dari kultur stok, kultur antara dan kultur kerja yang membutuhkan waktu selama tiga hari. Dalam rentang waktu ini kemungkinan akan terjadinya penurunan sifat dan mutu hasil akhir dari produk yang dihasilkan. Untuk mendapatkan produk yang berkualitas sebaiknya starter dilakukan proses adaptasi terlebih dahulu melalui tiga tahapan yaitu penyiapan kultur stok, kultur antara dan kultur kerja., sehingga butuh waktu 3-4 hari dalam penyiapan starter. Tahapan ini akan berpengaruh terhadap kelancaran proses produksi, oleh sebab itu perlu cara lain untuk dapat memperpendek waktu penyediaan starter dan mengatasi penurunan kualitas yoghurt serta memudahkan dalam penggunaan starter. Solusi yang ditawarkan adalah menyediakan starter probiotik dalam bentuk terenkapsulasi.

Enkapsulasi dibuat menggunakan karagenan yang disalut dengan skim sebagai pelindung. Penggunaan starter ini sangat membantu dalam menghasilkan yoghurt probiotik berkualitas dengan tampilan yang menarik, rasa enak, bergizi dan aman serta memberikan kemudahan dalam proses pembuatan produk. Peningkatan kapasitas produksi akan diiringi dengan peningkatan pemasaran, baik dilingkungan kampus dan permintaan dari masyarakat, kegiatan bazar dan pameran serta pemasaran secara online.

Aplikasi starter terenkapsulasi dalam pembuatan produk dalam bentuk bio-kapsul basah dengan menambahkan sebanyak 3\% ke dalam susu yang sudah dipasteurisasi. Pada kegiatan ini sekaligus dilakukan transfer teknologi kepada grup mahasiswa yang berwirausaha minuman probiotik. Implementasi dilakukan meliputi perbaikan proses produksi, diversifikasi produk, kemasan produk, analisa mutu dan kualitas produk serta manajemen dan pemasaran. Bahan baku utama untuk produksi seperti susu diperoleh dari unit Farm Politeknik dan bahan baku lainnya seperti jambu biji banyak tersedia di pasaran.

Buah Jambu Biji digunakan sebagai obat alami penyembuhan penyakit deman berdarah. Kaya akan vitamin C, vitamin A, vitamin K, likopen, asam folat, zat besi, serat yang terdapat dalam buah (Veratemala, 2018). Penggunaan jambu biji prebiotik sehingga membentuk konsep sinbiotik pre dan probiotik akan diperoleh efek promotif bagi kesehatan. Prebiotik jambu biji sebagai penyedia energi dan perangsang pertumbuhan serta daya tahan dari isolat probiotik dalam sistem pencernaan. Menurut Crittenden (1999) prebiotik adalah ingridien pangan yang tidak dapat dicerna tetapi memberikan efek yang menguntungkan bagi usus dan dapat meningkatkan kesehatan manusia

Menurut Abikusno (2006) fortifikasi penggunaan Probiotik dengan prebiotik dapat memperbaiki efek perlindungan usus besar terhadap berbagai berbagai mikroorganisme patogen dalam usus. Konsep-konsep prebiotik akan berpengaruh terhadap mikroekologi intestinal, dimulai dari: penelanan prebiotik, transfer prebiotik ke kolon, difermentasi oleh probiotik, dan perbaikan komposisi bakteri kolon (Jenie, 2001). Senyawa-senyawa ini berfungsi sebagai antikarsinogenik, antimikroba, memperbaiki aktivitas penyerapan mineral, efek ini akan dapat dicapai dengan mengkonsumsi 20 - 60 gr/hari (Crittenden, 1999).

Kegiatan ini bertujuan untuk meningkatkan kapasitas produksi kelompok usaha minuman probiotik dengan memproduksi yoghurt jambu biji yang bermutu dan bermanfaat untuk kesehatan dengan menggunakan starter Lactobacillus paracasei ssp paracasei ML3 terenkapsulsi.

Salah satu produk yang dikembangkan dalam kegiatan PPUPIK adalah yoghurt probiotik. Yoghurt merupakan produk susu terfermentasi, bentuknya mirip bubur atau es krim tetapi dengan rasa yang agak asam. Prinsip pembuatan yoghurt adalah upaya menumbuhkembangkan (inkubasi) bakteri pada susu. Rahmi dan Mutia (2017), menggunakan bakteri asam laktat asal dadih yaitu Lactobacillus paracasssei ssp paracasei Ml3 sebagai starter sebanyak $5 \%$ dan di inkubasi pada suhu $37^{\circ}$ selama 6-12 jam.

Beberapa permasalahan yang dapat disimpulkan dari uraian di atas antara lain:

1. Belum tersedianya starter probiotik yang mudah diaplikasikan untuk menghasilkan produk probiotik yoghurt

2. Belum tersedianya starter yang siap pakai.

3. Belum samanya mutu produk yoghurt yang dihasilkan

4. Penganekaragaman produk PPUPIK 
Solusi yang ditawarkan adalah mengembangan starter probiotik dalam bentuk enkapsulasi karagenan-skim yaitu Lactobacillus paracasei ssp paracasei M13 sebagai starter yang praktis untuk diaplikasikan.

\section{METODE PENERAPAN}

Kegiatan ini dilakukan pada tahun 2019 di labor Mikrobiologi dan labor Pengolahan Pangan dan Unit Bisnis Politeknik Pertanian, dengan teknik pengumpulan data primer dan skunder serta dilanjutkan analisisis data menggunakan SPSS.

Metode yang digunakan untuk menyelesaikan masalah diatas adalah:

1. Uji coba labor

Uji coba lab dilakukan untuk menghasilkan beads karagenan-skim dengan perbandingan $(1: 1 ; 2: 1 ; 3: 1)$ (metoda Tsen, Jen-Horng, Yeu-Pyng Lin, V. An-Erl King, June. 2003) yang dimodifikasi. Hasil terbaik diperoleh setelah dilakukan penghitungan rendemen, pengukuran diameter, pengujian viabilitas beads basah (Fardiaz, 1992). Perbandingan bahan pengisi terbaik akan digunakan sebagai starter dalam pembuatan yoghurt. Campuran dikocok dengan hati-hati lalu diinkubasi selama 12 jam pada suhu $43^{\circ} \mathrm{C}$. Perisa sari buah jambu biji hasil ekstraksi dan di pasteurisasi, kemudian dihomogenisasi dengan menambahkan sebanyak $7.5 \%$. Selanjutnya dilakukan pengemasan. Pengujian juga dilakukan pada yoghurt sari buah jambu biji yang meliputi penentuan kadar air (Metode Oven, AOAC. 1984), kadar Abu, kadar lemak, kadar protein (Metode Kjeldahl, AOAC, 1995), karbohidrat total, Trimedona 2016), $\mathrm{pH}$, total asam laktat dan total bakteri asam laktat (Fardiaz 1992).

2. Demonstrasi

Demonstrasi proses pembuatan yoghurt jambu biji menggunakan starter terenkapsulasi untuk meningkatkan kapasitas produksi yang dilanjutkan dengan proses pembimbingan produksi, pengemasan dan pemasaran produk. Demonstrasi dilakukan berulang ulang sampai dihasilkan yoghurt yang berkualitas, hasil demonstrasi akan dilakukan uji konsumen dan kemudian dilakukan produksi massal sebanyak 3 kali dalam seminggu (90 cup).

3. Pembimbingan dan evaluasi

Pembimbingan dan evaluasi dilakukan secara intensif terhadap kelompok usaha minuman probiotik, sehingga kelompok usaha dengan cepat mengadopsi teknologi yang diberikan dan menerapkannya. Pelaksanaan pembimbingan dilakukan secara langsung maupun tidak langsung satu minggu sekali. Pada tahapan ini dilakukan pencarian target-target pasar yang baru dengan mengkaji kendala atau masalah selama program berjalan, sehingga ditargetkan produksi atau keuntungan akan meningkat minimal $20 \%$. Pemasaran juga dilakukan melalui media sosial atau web (www.rumah probiotik.com).

\section{HASIL DAN KETERCAPAIAN SASARAN}

\section{Uji Coba Labor}

Starter terenkapsulasi karagenan-skim 2:1 menghasilkan rendemen beads yang tinggi sekitar 97\% dengan viabilitas 9,2 log CFU/g. beads digunakan sebagai starter sebanyak 3\% dengan cara memasukkan langsung butiran beads ke dalam susu pasterurisasi dan diinkubasi selama 12 jam pada suhu $43^{\circ} \mathrm{C}$. Perisa jambu biji diberikan sebanyak 7,5\% dalam bentuk layer pada kemasan cup. Hasil seperti terlihat pada Gambar 1, 2, dan 3.

Sebelum yoghurt diproduksi massal untuk dipasarkan dilakukan pengujian lab terlebih dahulu, dimana total asam laktat yoghurt adalah $1.09 \%$, dan $\mathrm{pH}$ 4.6. Total asam laktat yoghurt jambu biji adalah 1,09\%, $\mathrm{pH}$ 4.6, dan total bakteri asam laktat $8.3 \mathrm{Log} \mathrm{CFU} / \mathrm{g}$. Nilai total asam, dan jumlah bakteri asam laktat dalam oroiduk sudah memenuhi standar SNI yoghurt tahun 2009 (total asam 0,5-2\%, jumlah bakteri asam laktat minimal 7 Log CFU/g). Nilai $\mathrm{pH}$ dan rasa yang sedikit asam serta total asam yang dihasilkan sebagai aktivitas perombakan laktosa menjadi asam laktat. Keadaan ini akan berpengaruh terhadap jumlah bakteri asam laktat pada yoghurt yang bertahan hidup (Winarno dan Fernandez, 2007). Proses fermentasi yogurt menurut Sunarlim, Hadi, dan Masniari (2007), dilakukan sampai diperoleh pH akhir berkisar antara 3,8-4,6 diikuti dengan terbentuknya flavor yang khas karena terbentuknya asam laktat, asam asetat, asetaldehid, diasetil dan senyawa volatil lain. Hartati (2011) dalam penelitiannya menyatakan semakin besar total bakteri asam laktat, maka semakin besar pula laktosa dan gula yang dimanfaatkan. 


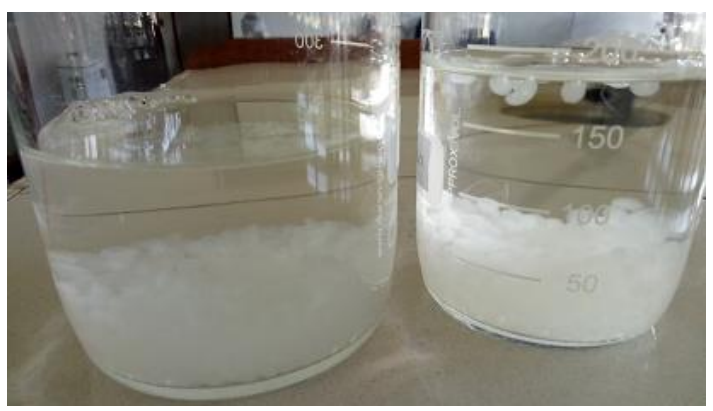

Gambar 1. Pembuatan bead basah karagenan-skim

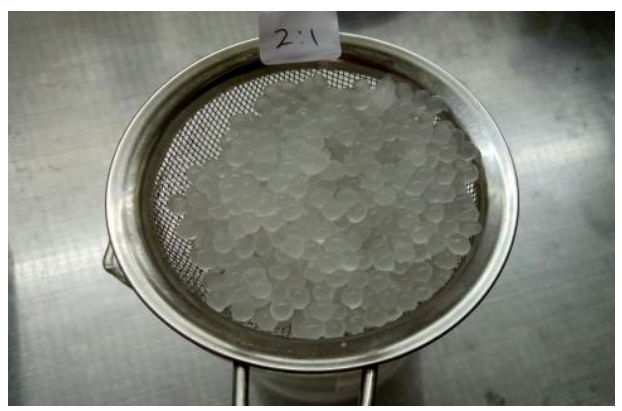

Gambar 2. Penyaringan beads

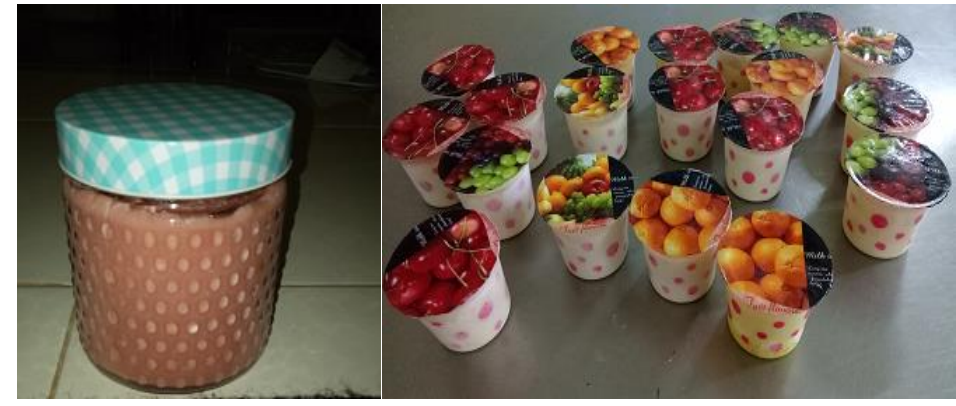

Gambar 3. Yoghurt jambu biji dan pengemasan yoghurt jambu biji

Untuk Hasil uji proksimat seperti pada Gambar 4.

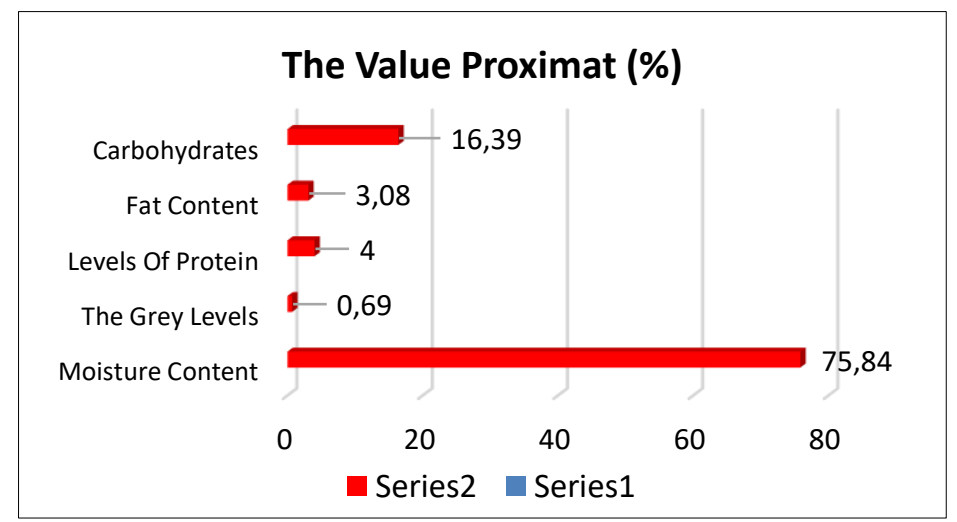

Gambar 4. Hasil pengujian proksimat yoghurt jambu biji (Yojabi) 
Dari Gambar 2 dapat dilihat kadar air yoghurt adalah 75.84, kadar air yoghurt dipengaruhi oleh bahan dasar susu, dan ekstrak jambu biji sebagai bahan cair yang mengandung air dalam jumlah yang banyak. Yoghurt tergolong makanan cair, makanan cair memiliki aw yang tinggi yaitu 0,99 , tetapi dengan keadaan $\mathrm{pH}$ yang rendah atau kondisi yang asam pertumbuhan mikroba dapat dihambat. Menurut Hartati (2011), terhambatnya pertumbuhan mikroorganime dalam bahan pangan yang diasamkan sehingga berbentuk padatan sehingga air tidak lagi dapat berfungsi sebagai pelarut dan media pertumbuhan mikoba. Dari data pada Gambar 1 terlihat yoghut yang dihasilkan sudah memenuhi syarat mutu yoghurt sesuai dengan SNI 2981:2009). Kadar abu maksimal yoghurt adalah 1.0\%, kadar protein minimal 2.7\%, kadar lemak minimal 3.0\%.

Keunggulan produk ini adalah mutu yang dihasilkan sudah memenuhi syarat mutu yang ditetapkan oleh SNI yoghurt, sehingga produk dapat diproduksi secara massal dan dapat memenuhi keinginan konsumen terhadap produk yang bermutu yang bermanfaat untuk kesehatan atau functional food. Produk Yojabi disebut produk probiotik karena menggunakan starter pobiotik yang sudah dikarakterisasi sebagai bakteri probiotik.

\section{Pembimbingan dan evaluasi}

Dari hasill analisa financial diperoleh $\mathrm{R} / \mathrm{C}$ ratio 1.48 dan BEP produk $\mathrm{Rp} 3.382,30$. Produk dijual dengan harga per cup Rp 5.000, produksi dilakukan sebanyak 3 kali seminggu menggunakan starter dalam bentuk beads basah dengan produksi sebanyak 90 cup serta kenaikan keuntungan $20 \%$ tahun. Sistim pamasaran yang dilakukan adalah pemasaran langsung ke konsumen, dan promosi dilakukan secara online dan menggunakan website www.rumah probiotik.com. Pemasaran menggunakan media sosial dan pengantaran ke konsumen langsung dapat meningkatkan kapasitas produksi sekitar 20\% setiap tahunnya

\section{KESIMPULAN}

Penyediaan starter untuk pembuatan yoghurt sudah tersedia dengan baik dan sudah diaplikasikan dalam pembuatan Yojabi. Starter probiotik tersedia dalam bentuk beads basah terenkapsulasi karagenan-skim yang mengandung bakteri Lactobacillus paracasei ssp paracasei ML3 sudah diaplikasikan dalam pembuatan yoghurt jambu biji (Yojabi). Pemakaian sebanyak 3\% dengan menghasilkan Yojabi yang memenuhi standar mutu sesuai SNI yoghurt 2981:2009. Analisa finansial produk Yojabi dengan R/C 1.48 dengan kenaikan jumlah produksi dan keuntungan 20\%/tahun. Rekomendasi untuk kegiatan selanjutnya adalah penyediaan starter probiotik dalam bentuk beads kering sehingga mudah dalam penyimpanan dan pengawetan sehingga tidak terjadi penurunan mutu produk. Starter bisa diapliaksikan pada pelaku usaha peternak sapi perah atau peternak kerbau dalam memproduksi dadih yang berkualitas.

\section{UCAPAN TERIMA KASIH}

Ucapan terimakasih kepada Kementerian Riset Teknologi dan Pendidikan Tinggi atas bantuan dana dan hibah yang diberikan.

\section{DAFTAR PUSTAKA}

Abikusno, R. M. N. 2006. Prebiotik \& Probiotic Manfaat bagi Kesehatan. Pusat jantung Nasional Harapan Kita. http://www.pjnhk.go.id/index.php? option=com_content\&task=view\&id=439\&Itemid=31. Diakses pada 21 September 2018.

AOAC. 1984. Official Methods of Analysis. AOAC (Association of Official Analytical Chemist). Virginia: Inc., Arlington.

AOAC. 1995. Official Methods of Analysis. AOAC (Association of Official Analytical Chemist). Virginia: Inc., Arlington.

Crittendan, R. G. 1999. Prebiotics. In: Tannock GW, editor. Probiotics A Crtical Review. England: Horizon Scientific $\operatorname{Pr}$.

Fardiaz, S. 1992. Analisis Mikrobiologi Pangan. Jakarta: PT. Raja Grafindo Persada.

Hartati, A. I. 2011. Kadar Laktosa, Total Gula Reduksi, pH, dan Rasa Yogurt Drink Berflavor Kurma (Phoenix dactylifera) sebagai Minuman Probiotik. Fakultas Peternakan Universitas Diponegoro, Semarang. Skripsi Sarjana Peternakan. 
Jenie, B. S. L. 2001. Prebiotik untuk kesehatan pencernaan. Makalah disajikan dalam seminar sehari tentang Kesehatan untuk Anak. Jakarta: PT. Nestle.

Rahmi, R., \& Mutia. E. 2017. Pembuatan Ice Krim Yoghurt. Payakumbuh: Politeknik Pertanian Negeri.

Sunarlim, H. S, \& Mariani, P. 2017. Pengaruh Kombinasi Starter Bakteri Lactobacillus bulgaricus, Streptococcus thermopilus and Lactobacillus plantarum on Quality of Fermented Milk. Seminar Nasional Peternakan dan Veteriner.

Trimedona. 2016. Kimia dan analisa pangan II. Buku Kerja Praktek Mahasiswa. Payakumbuh: Politeknik Pertanian Negeri Payakumbuh.

Tsen, J. H., Y. Lin., \& V. A. King. 2003. Fermentation of Banana Media by Using K-Carrageenan Immobilized Lactobacillus achidophilus. International Journal of Food Microbiology 91(2004): 215-220.

Veratemala, A. 2018.https://hellosehat.com/hidup-sehat/fakta-unik/6-manfaat-jambu-biji-buah-daun. Diakses pada 15 November 2018.

Winarno, F. G., \& I. E. Fernandez. 2007. Susu dan Produk Fermentasinya. Bogor: M-BRIO Press. 